\title{
POLICY RATES PASS-THROUGH IN INDONESIA'S DUAL BANKING SYSTEM: DOES BUSINESS CYCLE MATTER?
}

\author{
Sugeng Triwibowo ${ }^{1}$, Defy Oktaviani ${ }^{2}$, Adhitya Ginanjar ${ }^{3}$ and \\ Danu F. Ardiansyah ${ }^{4}$ \\ ${ }^{1}$ Coordinating Ministry for Economic Affairs, Indonesia, sugeng3wibowo@gmail.com \\ ${ }^{2}$ Ministry of Trade, Indonesia, defy.oktaviani81@alumni.ui.ac.id \\ ${ }^{3}$ UIN Syarif Hidayatullah, Indonesia, adhitya@uinjkt.ac.id \\ ${ }^{4}$ Universitas Islam Indonesia, Indonesia, danu.ardiansyah@students.uii.ac.id
}

\begin{abstract}
This paper examines the pass-through of the policy rate to conventional and Islamic bank rates during the recessionary and expansionary episodes for the case of Indonesia. Applying an error-correction modelling to monthly data from June 2014 to April 2021, our findings confirm that the interest rate pass-through is sensitive to the business cycle for both conventional and Islamic banks. The policy rate pass-through to deposit rates is higher during the recession for both banking types. We also note that the lending rates of conventional banks fully adjust to the policy rate in the recessionary phase. The findings for Islamic financing rates are interesting. Namely, they tend to move inversely with the policy rates during the expansionary period. Meanwhile, depending on the rates, they are either over-responsive or less responsive during the recessionary phase. Finally, the degree of short-run adjustment in most banking rates is not influenced by the business cycle. These findings suggest that Islamic banking rates are less synchronized to the monetary policy rate, indicating that sharia-based banking barely supports counter-cyclical monetary policy.
\end{abstract}

Keywords: Monetary policy pass-through, Dual banking, Business cycle.

JEL classification: E52; E32; G21.

Article history:

Received : : August 31, 2021

Revised : November 22, 2021

Accepted : February 1, 2022

Available online : February 28, 2022

https://doi.org/10.21098/jimf.v8i1.1424 


\section{INTRODUCTION}

\subsection{Background}

Understanding the monetary policy transmission process is crucial for guiding monetary policy decisions and assessing policy effectiveness (Atkin \& La Cava, 2017). Theoretically, monetary policy is propagated through several transmission channels, among which are interest rate, credit, exchange rate, and asset price channels (Cevik \& Teksoz, 2013; Boivin, Kiley \& Mishkin, 2010). According to the interest rate channel, which is generally considered as the main channel, the changes in monetary policy would first affect bank rates. Since bank financing rates are a key determinant of components of aggregate demand in particular household consumption of durable goods and firms' investment, the changes in financing rates would lead to changes in the aggregate demand and subsequently real output and the price level. This interest rate channel is normally depicted as:

\section{$\downarrow$ Policy rate $\rightarrow \downarrow$ bank rates $\rightarrow \uparrow$ investment, consumption $\rightarrow \uparrow \mathrm{AD} \rightarrow \uparrow$ GDP, $\mathrm{P}$}

where $\mathrm{AD}$ is aggregate demand, GDP is real gross domestic product and $\mathrm{P}$ is the price level. As may be discerned from the above transmission, the effectiveness of the monetary policy hinges crucially on the extent to which the policy rate is passed through the bank rates, the so-called interest rate pass-through (henceforth IRPT). More specifically, For the monetary policy to be effective in influencing real economic activity, the IRPT must be complete and symmetric (Hofmann \& Mizen, 2004; Apergis \& Cooray, 2015; Handayani \& Kacaribu, 2021).

The recent emergence of Islamic banking in many countries has stimulated much interest in especially its role in the monetary transmission mechanism. Unlike interest rate instruments in conventional banking, Islamic banking adopts the profit/loss sharing, margin, fee, or equivalent rates in their financial transactions (Ascarya, 2012). Given the demarcation of Islamic banking from interest rates and its close tie to the real sector, the pass-through of the policy rate to Islamic banks may be different. Thus, for countries where Islamic banking has assumed a prominent role such as Indonesia, the question as to how Islamic banks respond to the policy rate would be of great interest, particularly to monetary authorities. While there are many studies that have examined the responses of Islamic bank financing to changes in the interest rate (the so-called credit channel), studies on interest rate pass-through is limited and their findings are at best mixed. Thus, our current understanding of the IRPT to Islamic banks remains incomplete.

In views of this, the present paper analyzes the IRPT to Islamic banks in a dual banking system, i.e. Indonesia. In contributing to the limited literature on Islamic banking IRPT, our analysis covers three main aspects. First, as in many empirical studies on Islamic banking, we take a comparative perspective by examining the IRPT to both conventional and Islamic bank rates. Second, we look at various bank rates, which include money market rates, deposit rates (demand deposits, savings deposits and time deposits at various maturities) and lending/financing rates (Working Capital, Investment and Consumption). Thus, our analysis is more comprehensive than existing studies on the issue for Islamic banks. Finally, we also assess whether the IRPT depends on the phases of the business cycle. In the literature, various studies have noted that the effect of monetary policy is 
asymmetric with regard to the phases of the business cycle (Aragon \& Portugal, 2009). The impact of monetary policy on output is more substantial during the recession in the U.S., Germany, French, Spain, Austria, and Belgium (Garcia \& Schaller, 2002; Dolado \& Maria-Dolores, 2006; Peersman \& Smets, 2001; Kaufmann, 2002). Jannsen et al. (2019) also finds that the effect of monetary policy is substantially different during the financial crisis than those in stable times. Other studies further note that the interest rate monetary policy channel is ineffective during the period of high uncertainty (Bernanke, 1983; Dixit \& Pindyck, 1994). We add to this literature by bringing the Islamic banking perspective into the focus.

The rest of the article is organized as follows. Section II presents the literature review. The methodology is presented in Section III. Section IV discusses the empirical results and Section $\mathrm{V}$ concludes.

\section{LITERATURE REVIEW}

While the interest rate channel of monetary transmission mechanism is well acknowledged, how effective and strong the channel in transmitting monetary policy impulses to the real sector remains a matter of debate and of empirical inquiry. As the strength of this channel depends fundamentally on the IRPT (Gregor, Melecky \& Melecky, 2019; Hofmann \& Mizen, 2004; Apergis \& Cooray, 2015). i.e. the degree to which the policy rate is passed through to bank rates, many studies have made attempts to quantify the magnitudes of the pass-through. The literature is voluminous covering both individual countries as well as groups of countries. In general, existing studies tend to suggest different degrees of passthrough across countries, across banks and even across times. They note that there may be various factors that influence the IRPT, among which include economic and market conditions and adjustment costs (Sander \& Kleimeier, 2004; Stiglitz \& Weiss, 1981; Holton \& Rodriguez d'Acri, 2018; Avouyi-Dovi et al., 2017; Chong, 2010; Zulkhibri, 2012; Handayani \& Kacaribu, 2021; and Li, Si \& Ge, 2021).

Normally, central banks perform countercyclical monetary policy in responses to the business cycle. That is, they cut the interest rate during the recessionary period to stimulate the economy and raise the interest rate during the expansionary period to prevent overheating (Takáts, 2012). Yet, interestingly, the business cycle itself can potentially affect the IRPT. While many studies have found the passthrough to be asymmetric across the business cycle or be different during the downturns, the evidence is still inconclusive as to whether the pass-through is higher or lower during recession or crisis periods. For instance, several studies have confirmed that the interest rate pass-through is weakened during the global financial crisis for the cases of Europe and the USA (Karagiannis, Panagopoulos \& Vlamis, 2010; Hristov, Hülsewig \& Wollmershäuser, 2014; Aristei \& Gallo, 2014). These studies note that he IRPT had been complete before the crisis but has turned incomplete since the crisis started. By contrast, Humala (2005) find that the magnitude of Argentina's IRPT is higher for all interest rates during the financial crises. Furthermore, other studies report that the crisis period had no significant effect on the degree or speed of IRPT in the Malaysia and Turkey cases (Yüksel \& Özcan, 2013; Hussain \& Nahar, 2016). 
Unlike the conventional banking system, Islamic banking follows the Sharia principle, which prohibits the practice of interest or Riba (Abedifar, Ebrahim, Molyneux \& Tarazi, 2015). Islamic banking adopts a profit-loss sharing system based on the profit/loss occurring in the debtor's business. Abedifar et al. (2015) classify transactions in Islamic banking, which is based on Fiqh Muamalah, into three categories, namely debt-based financing, lease-based financing, and profit-sharing or lost financing (PSL). This practice makes Islamic banking more dependent on the real sector (Fikri, 2018) and reduces the risk of the creditors and debtors during a time of uncertainty (Bilgin, Danisman, Demir \& Tarazi, 2021).

In dual banking regimes, where the typical conventional money market is more developed, and interest rate system is dominant, there is a tendency of a spillover effect to Islamic banks funding costs from conventional bank rates, to profit-sharing investment account (PSIA) return and to Islamic banks credit costs (Cevik \& Charap, 2011). The early stage of Islamic banks' development is often characterized by the lack of Islamic finance equivalent to money market and government bond rates as reference rates to Islamic banks credit rates. Consequently, Islamic banks tend to link the rate of Murabaha and Ijarah contracts to conventional interest rates (Zaheer, Ongena \& van Wijnbergen, 2013).

Conventional and Islamic banking are fundamentally different. While conventional banking uses the interest system, Islamic banking uses profit/ loss sharing (Ryandono, 2006; Ascarya, 2007). This characteristic is expected to affect how conventional and Islamic banking systems administer their respective banking rates and respond to the monetary policy rate changes. Nevertheless, Zulkhibri (2018) and Omer (2019) find that although Islamic banks are assumed to be interest-rate free, their lending behavior's responses to the policy rate change are similar to conventional banks.

Some studies have been carried out to compare the responses of Islamic and conventional banks to monetary policy changes. Akhatova, Zainal \& Ibrahim (2016) find significant response of credit and financing in conventional and Islamic banks to the change of monetary policy. In addition, when the interest rates increase, Islamic financing is likely to respond faster than conventional banks. Kassim, Majid \& Yusof (2009) and Aysan, Disli \& Ozturk (2018) also discover that credit and loans in Islamic banks are more responsive to the change in monetary policy compared to their conventional counterparts. The study conducted in Pakistan by Omer (2019) examines the policy rate pass-through to conventional banks and Islamic banks. He finds a similar pass-through of policy rate to retail prices of both banks types. By contrast, Caporale et al. (2020) argue that the response of Islamic banks' credit to policy rate changes is not as sensitive as conventional banks' credit. However, both responses have become more similar in recent years.

In Indonesia, for the conventional bank case, Handayani \& Kacaribu (2021) note that switching the benchmark rate from BI Rate to 7-Day Repo Rate (7DRR) has improved the IRPT to the money market rate. However, the pass-through to deposit and lending rates have turned incomplete. In addition, lending rates respond asymmetrically during the monetary tightening and easing. The monetary policy transmission through the interest rate channel is also significant in the Islamic bank system in Indonesia (Sukmana, 2015; Audah \& Kasri, 2020). Ascarya (2012) investigates the monetary policy transmission via Islamic and conventional 
banks to inflation and output. He notes that conventional rate is propagated to inflation and output while Islamic rate fails to do so. Moreover, conventional policy rate shock brings negative and permanent impacts on inflation and output; meanwhile, Islamic policy rate shock brings positive and permanent impacts on inflation and output in Indonesia.

Although the number of Islamic banks is growing, the research on the IRPT in Indonesia's Islamic banking is still limited. Zulkhibri \& Sukmana (2017) use panel data of Indonesian Islamic banks between 2003 and 2014 and find that Islamic banks' financing is insensitive to the change of monetary policy rate. Furthermore, Hafidh (2021) demonstrates that the transmission of monetary policy changes to the real sector, i.e., inflation, is weaker in Islamic banking as compared to conventional banking. However, none of the studies has explored the behavior of IRPT in conventional and Islamic banking during recession or expansion periods. Therefore, we contribute to the literature by comparing the IRPT in Indonesia's dual banking system during the different phases of the business cycle.

\section{METHODOLOGY}

\subsection{Data}

We compile monthly data covering the period from June 2014 to April 2014. Three sets of bank rates are considered. These are the money market, deposit, and lending/financing rates. The specific rates for both Islamic and conventional banks are given in Table 1 below. As for the monetary policy rate, we employ the benchmark interest rate announced regularly by Bank Indonesia. Finally, to identify the phases of the business cycle, whether the economy is in recession or in expansion, we use the output gap estimated using the standard Hodrick-Prescott (HP) Filter. The filter decomposes a time series into a scalar trend (long-term trend) and a cyclical component. Suppose, a time series variable $y^{t}$, for $t=1,2, \ldots, \mathrm{T}$, consist of a trend $\left(y^{T}\right)$ and cyclical $\left(y^{C}\right)$ components, $y_{t}=y^{T}+y^{C}$. Following Hodrick-Prescott (1997), the filter is given by:

$$
\left\{\sum_{t=1}^{T}\left(y_{t}-y_{t}^{C}\right)^{2}+\lambda\left[\left(y_{t+1}^{C}-y_{t}^{C}\right)-\left(y_{t}^{C}-y_{t-1}^{C}\right)\right]^{2}\right\}
$$

where $\lambda$ is a smoothing constant to penalize the variation in the growth rate of the scalar trend component. As Hodrick \& Prescott (1997) propose, the common practice is that the value of quarterly data is 1600 . We use quarterly data of Real GDP from the IMF database. 
Table 1.

Banking Rates and Its Data Source

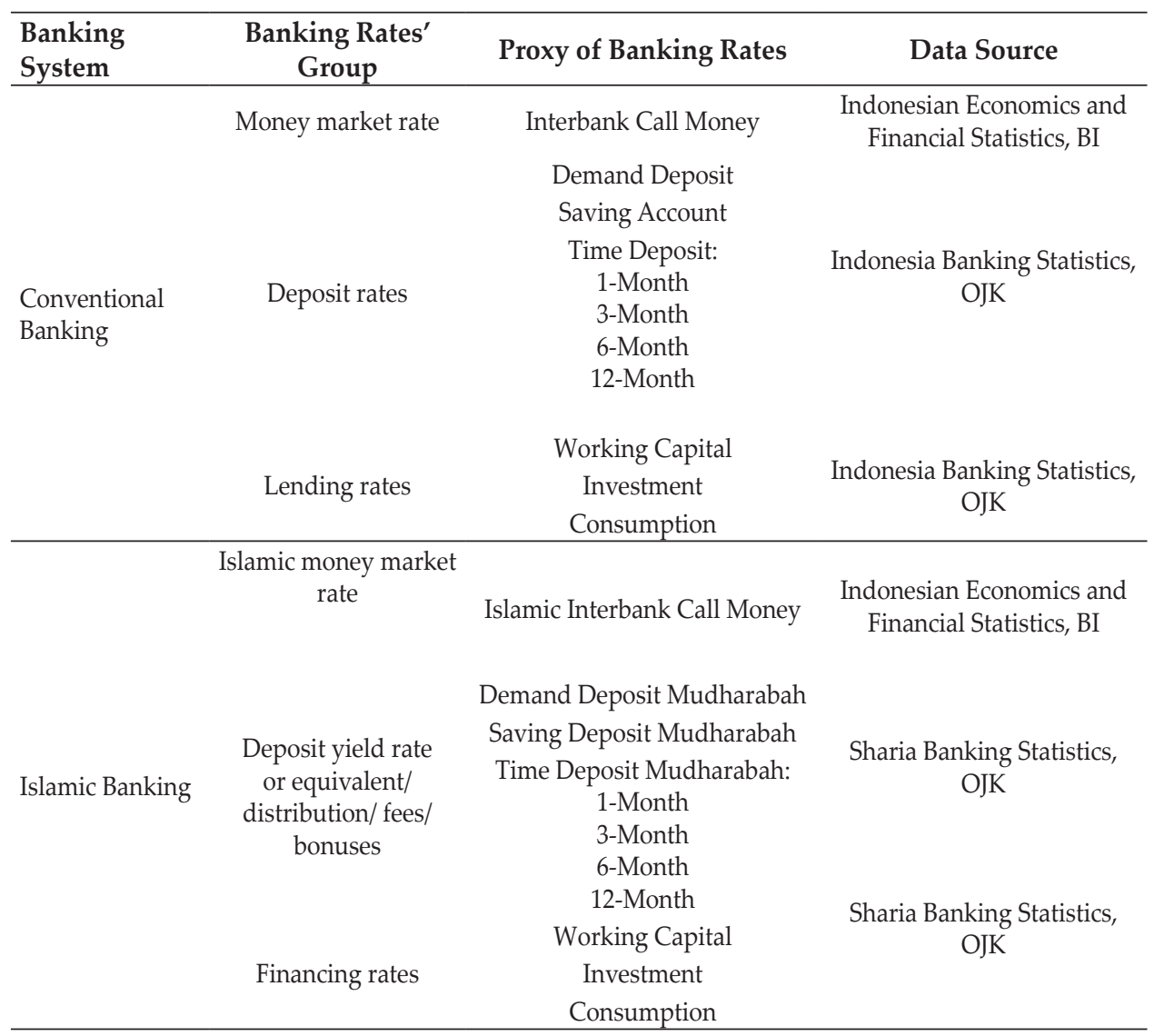

Sources: Indonesian Economics and Financial Statistics, Indonesia Banking Statistics, and Sharia Banking Statistics published monthly at the Bank Indonesia (BI) and Indonesian Financial Service Authority (OJK) websites.

\subsection{Empirical Models}

Following Chong (2010), Liu, Margaritis \& Qiao (2016), and Handayani \& Kacaribu (2021), the present paper employs the two-step Error Correction Model (ECM) to examine the policy rate pass-through to both Islamic and conventional bank rates. The model incorporates asymmetry in the responses bank rates to monetary policy rates change during the contractionary and expansionary periods.

In the first step of ECM, we set up the following long-run equation that links bank rates to the monetary policy rate:

$$
I R_{t}=\alpha_{0}+\alpha_{1} P R_{t}+\alpha_{2} D+\alpha_{3} D * P R_{t}+\varepsilon_{t}
$$

where $I R_{t}$ represents bank rates (conventional and Islamic banking), $P R_{t}$ is the policy rate, $t$ denotes time, and $\varepsilon_{t}$ is the error term. $\mathrm{D}$ is the business cycle dummy variable, which takes the value of 1 if the period is in recession and 0 otherwise. 
As explained above, we identify recession using the HP-filtered output gap, where negative output gap signals recession.

In (1), the coefficient $\alpha_{0}$ represents intermediation cost or margin, which comprises mark-up and marginal cost. Furthermore, $\alpha_{1}$ measures the long-run interest rate pass-through during the expansion period. We expect $\alpha_{0}$ and $\alpha_{1}$ to be positive. The parameter $\alpha_{2}$ measures the change in the intermediation cost or margin during recession. Finally, $\alpha_{3}$ captures the difference in the pass-through between the recessionary and expansionary periods. In other words, while $\alpha_{1}$ measures the long-run interest rate pass-through during the expansion period, $\alpha_{1}+\alpha_{3}$ measures the pass-through during the recessionary period. Note that the IRPT is complete when they are statistically indistinguishable from (one-to-one) and incomplete (over-complete) when they are less than (more than) one. Finally, when the movement of banking rates as the response of monetary policy rates is showing opposing behavior, we label it as reverse adjustment.

In estimating equation (1), we first conduct the unit root test of the residual term to check the presence of cointegration (Valadkhani \& Anwar, 2012). Then, after verifying their long run relation, we apply Wald Test to establish whether the long-run interest rate pass-through is complete or not. When the economy is not experiencing a recession, the null hypothesis is $H_{0}: \alpha_{1}=1$ and the alternative hypothesis is $H_{1}: \alpha \neq 1$. However, in the recessionary phase, we test the hypothesizes $H_{0}: \alpha_{1}+\alpha_{3}=1$ against $H_{1}: \alpha_{1}+\alpha_{3} \neq 1$. Moreover, another Wald test is also performed to check the hypothesis $H_{0}: \alpha_{1}=\alpha_{1}+\alpha_{3}$ against $H_{1}: \alpha_{1} \neq \alpha_{1}+\alpha_{3}$ which represent the change in long-run IRPT between different phases of the business cycle.

Then, in the second stage of the ECM model, the short-run dynamics of banking rates are analyzed. The focus is on the speed of adjustment and the direct pass-through. The short-run dynamics, as well as the adjustment, is captured by the following equations:

$$
\Delta I R_{t}=\beta_{1} \Delta P R_{t}+\beta_{2} \varepsilon_{t-1}+\beta_{3} D * \Delta P R_{t}+\beta_{4} D * \varepsilon_{t-1}+\mu_{t}
$$

where $\Delta$ symbolizes the first difference operator and $\mu_{t}$ is the error term. The variable $\varepsilon_{t-1}$ is the residual from equation (1) and describes the divergence of the interest rate from its long-run equilibrium level in the previous period. The parameter $\beta_{1}$ denotes the magnitude of immediate pass-through. In addition, coefficients $\beta_{2}$ represents the speed of adjustment when the economy is in expansion. The dummy of recession is also incorporated in (2) to capture the differences in the short-term relationship between the policy rates and interest rates during recessionary and expansionary conditions. Coefficient $\beta_{3}$ measures the difference in the degree of IRPT in the short-run while parameter $\beta_{4}$ different in error-correction adjustment speed during the expansion period as compared to those during the recessionary period.

Furthermore, we calculate the Mean Adjustment Lag (MAL) as suggested by Liu et al. (2016) for the expansionary and contractionary period. MAL describes a combination of magnitude and adjustment speed of short term pass-through. MAL in expansionary period is calculated as $\left(1-\beta_{1}\right) / \beta_{2}$, while in recessionary period it is computed as $\left(1-\left(\beta_{1}+\beta_{3}\right) /\left(\beta_{2}+\beta_{4}\right)\right.$. 


\section{RESULTS AND ANALYSIS}

\subsection{Business Cycle}

Figure 1 illustrates the output gap in Indonesia during the period 2005 to early 2021. As may be noted from the figure, Indonesia entered inti the contractionary phase from 2014 to June 2017, followed by an expansionary phase from July 2017 to March 2020. Due to Covid-19 Pandemic, Indonesia experienced a contractionary episode that started in April 2020 until the end of the observation study, April 2021.

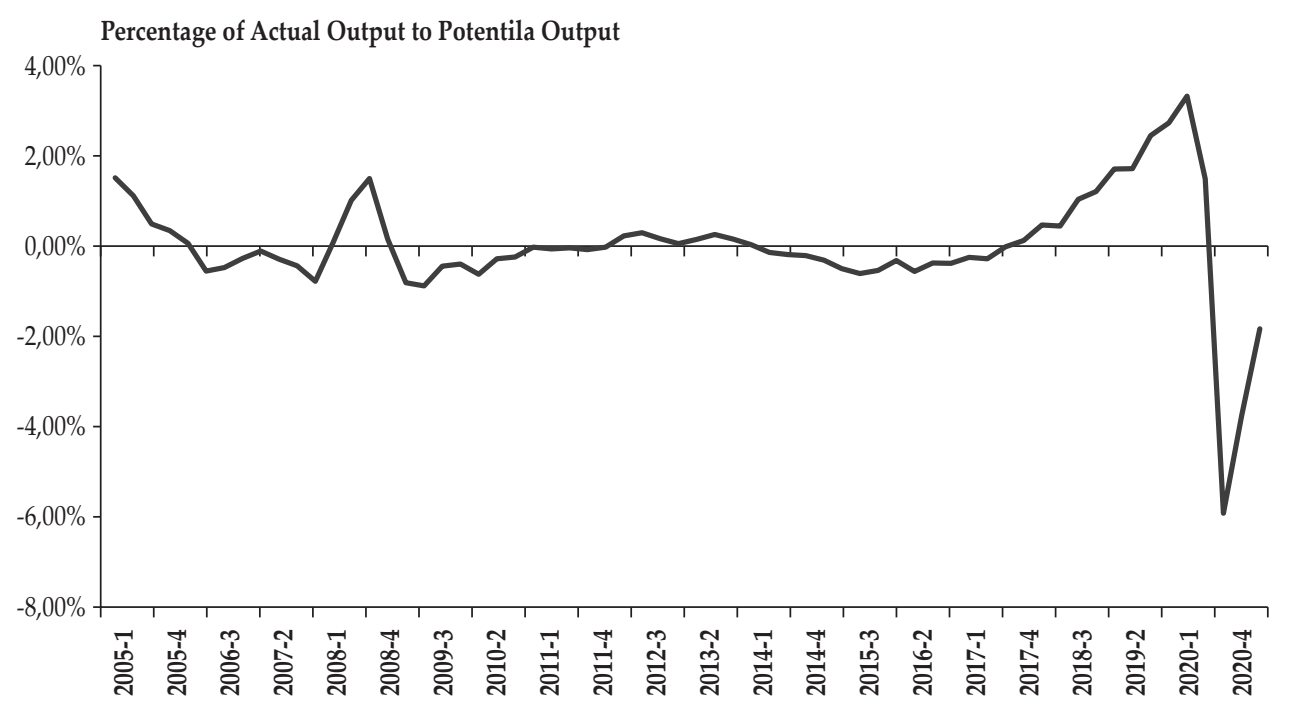

Source: Author's Calculation

Figure 1.

The Output Gap in Indonesia (2005-2021)

\subsection{Correlation Analysis}

Before examining the long-run relationship between the policy rate and banking rates, we analyze their pairwise correlations. From the correlation coefficients presented in Table 2, we find some interesting results. In general, the policy rate is more correlated with conventional banking interest rates than the Islamic banking rates. Further, banking rates of both conventional and Islamic banking tend to correlate more with the policy rate during the contractionary phase. We may also note that, during the expansionary phase, the deposit and financing rates of Islamic Banking are inversely related to the policy rate. Finally, among the rates considered in this study, the money market rates are most correlated with the policy rate. Then, among the deposits, demand deposit rates are the least correlated with the policy rate while, among the fining rates, lending or financing rates for consumption have the lowest correlation with the policy rate. 
Table 2.

Correlation Analysis

\begin{tabular}{|c|c|c|c|c|c|}
\hline \multicolumn{3}{|c|}{ A. Conventional Banking } & \multicolumn{3}{|c|}{ B. Islamic Banking } \\
\hline \multicolumn{6}{|c|}{ Benchmark Monetary Policy Rate } \\
\hline (1) & (2) & (3) & (4) & (5) & (6) \\
\hline $\begin{array}{l}\text { Proxy of } \\
\text { Interest Rate }\end{array}$ & $\begin{array}{c}\text { Expansionary } \\
\text { Phase }\end{array}$ & $\begin{array}{c}\text { Contractionary } \\
\text { Phase }\end{array}$ & $\begin{array}{c}\text { Proxy of } \\
\text { Interest Rate }\end{array}$ & $\begin{array}{c}\text { Expansionary } \\
\text { Phase }\end{array}$ & $\begin{array}{c}\text { Contractionary } \\
\text { Phase }\end{array}$ \\
\hline \multicolumn{6}{|c|}{ Money Market } \\
\hline $\begin{array}{l}\text { Interbank } \\
\text { Call Money }\end{array}$ & $0.955^{*}$ & $0.903^{*}$ & $\begin{array}{c}\text { Sharia } \\
\text { Interbank } \\
\text { Call Money }\end{array}$ & $0.462^{*}$ & $0.855^{*}$ \\
\hline \multicolumn{6}{|c|}{ Deposit Rates/Yield Rate or Equivalent } \\
\hline $\begin{array}{l}\text { Demand } \\
\text { Deposit }\end{array}$ & -0.132 & $0.801^{*}$ & $\begin{array}{c}\text { Demand } \\
\text { Deposit } \\
\text { Mudharabah }\end{array}$ & $0.536^{*}$ & -0.208 \\
\hline $\begin{array}{l}\text { Saving } \\
\text { Account }\end{array}$ & $-0.605^{*}$ & $0.885^{*}$ & $\begin{array}{c}\text { Saving } \\
\text { Deposit } \\
\text { Mudharabah }\end{array}$ & $-0.527^{*}$ & $0.952^{*}$ \\
\hline Time Deposit & & & $\begin{array}{l}\text { Time Deposit } \\
\text { Mudharabah }\end{array}$ & & \\
\hline 1-Month & $0.921^{*}$ & $0.941^{*}$ & 1-Month & -0.138 & $0.972^{*}$ \\
\hline 3-Month & $0.790^{*}$ & $0.949^{*}$ & 3-Month & -0.092 & $0.977^{*}$ \\
\hline 6-Month & $0.683^{*}$ & $0.957^{*}$ & 6-Month & $-0.497^{*}$ & $0.939^{*}$ \\
\hline 12-Month & 0.2806 & $0.949^{*}$ & 12-Month & -0.276 & $0.947^{*}$ \\
\hline \multicolumn{6}{|c|}{ Lending Rates/ Financing Rates } \\
\hline $\begin{array}{l}\text { Working } \\
\text { Capital }\end{array}$ & $-0.394^{*}$ & $0.930^{*}$ & $\begin{array}{l}\text { Working } \\
\text { Capital }\end{array}$ & $-0.652^{*}$ & $0.893^{*}$ \\
\hline Investment & -0.285 & $0.913^{*}$ & Investment & $-0.701^{*}$ & $0.928^{*}$ \\
\hline Consumption & $-0.738^{*}$ & 0.751 & Consumption & $-0.503^{*}$ & $0.784^{*}$ \\
\hline
\end{tabular}

The Table provides information on the correlation coefficient based on Pearson correlation estimation between each type of administered banking interest rate to benchmark monetary policy rate during the expansionary and contractionary phases. Columns (2) and (3) present the correlation coefficient matrix for the conventional banks while columns (5) and (6) deliver information on the correlation coefficient for the Islamic banks. ${ }^{*}=$ significant at $5 \%$

\subsection{The Long-Run Relations}

We first conduct the Augmented Dickey-Fuller (ADF), the Phillips-Perron (PP), and the Kwiatkowski-Phillips-Schmidt-Shin (KPSS) unit root tests to check the stationarity of the series. The results, which are presented in Table 4, generally suggest all rates are non-stationary integrated of order (1).

The estimation results of long-run equation (1) are presented in Table 4. As suggested by Rousseas (1985), the parameter $\alpha_{0}$ represents the intermediation cost or margin. Our results show that the margins of Islamic banking are generally higher than those of conventional banking for both deposit and lending or financing margins. Except for the demand deposit margin, all the time deposit and saving deposit margins are higher for deposit rates. The time deposit mudharabah rate is $6.35 \%$, while the time deposit rate is $5.12 \%$ on average. Likewise, for lending or financing rates, lending rates for conventional banking range from $10 \%$ to $14 \%$, lower than financing rates in Islamic banking, which range from $12 \%$ to $15 \%$. This 
finding collaborates Ibrahim \& Law (2019) for Malaysia and Trinugroho, Risfandy \& Ariefianto (2018) for Indonesia.

From the results, we argue that although Islamic banks operate under distinct institutions, an interest-based monetary policy instrument we use as policy rate reference has been passing through to Sharia banks rates. Our results provide empirical evidence of a spillover effect that has been suggested by previous literature (Cevik \& Charap, 2011; Zaheer et al., 2013; Hamza \& Saadaoui, 2018).

Table 3.

Unit Root Tests

\begin{tabular}{|c|c|c|c|c|c|c|}
\hline \multirow[b]{2}{*}{ Variable } & \multicolumn{2}{|c|}{ ADF } & \multicolumn{2}{|r|}{ PP } & \multicolumn{2}{|c|}{ KPSS } \\
\hline & Levels & $\begin{array}{c}\text { First } \\
\text { Difference }\end{array}$ & Levels & $\begin{array}{c}\text { First } \\
\text { Difference }\end{array}$ & Levels & $\begin{array}{c}\text { First } \\
\text { Difference }\end{array}$ \\
\hline $\begin{array}{l}\text { Benchmark Monetary } \\
\text { Policy Rate }\end{array}$ & -2.57 & -2.02 & -1.46 & $-13.15^{* * *}$ & $0.53^{* *}$ & 0.11 \\
\hline \multicolumn{7}{|c|}{ A. Conventional Banking } \\
\hline \multicolumn{7}{|c|}{ Money Market } \\
\hline Interbank Call Money & -0.42 & $-11.28^{* * *}$ & -1.95 & $-14.09^{* * *}$ & $0.61^{* *}$ & 0.11 \\
\hline \multicolumn{7}{|l|}{ Deposit Rates } \\
\hline Demand Deposit & 0.57 & $-11.89^{* * *}$ & 0.085 & $-11.68^{* * *}$ & $0.94^{* * *}$ & 0.24 \\
\hline Saving Account & 1.98 & $-7.64^{* * *}$ & 1.88 & $-7.68^{* * *}$ & $1.11^{* * *}$ & $0.75^{* *}$ \\
\hline \multicolumn{7}{|l|}{ Time Deposit } \\
\hline 1-Month & -0.16 & $-5.32^{* * *}$ & 0.17 & $-5.38^{* * *}$ & $0.98^{* * *}$ & 0.18 \\
\hline 3-Month & -0.65 & $-3.93^{* * *}$ & 0.08 & $-3.97^{* * *}$ & $1.06^{* * *}$ & 0.17 \\
\hline 6-Month & -0.56 & $-2.72^{*}$ & 0.21 & $-4.03^{* * *}$ & $1.06^{* * *}$ & 0.16 \\
\hline 12-Month & -0.00 & $-3.75^{* * *}$ & 0.71 & $-5.77^{* * *}$ & $0.98^{* * *}$ & 0.24 \\
\hline \multicolumn{7}{|c|}{ Lending Rates } \\
\hline Working Capital & 0.93 & $-8.51^{* * *}$ & 0.67 & $-8.55^{* * *}$ & $1.10^{* * *}$ & 0.19 \\
\hline Investment & 1.77 & $-4.47^{* * *}$ & 1.24 & $-8.87^{* * *}$ & $1.10^{* * *}$ & 0.27 \\
\hline Consumption & -0.10 & -2.50 & 0.83 & $-6.97^{* * *}$ & $1.04^{* * *}$ & $0.51^{* *}$ \\
\hline
\end{tabular}

B. Islamic Banking

\begin{tabular}{lcccccc}
\hline \multicolumn{7}{c}{ Islamic Money Market } \\
\hline Sharia Interbank Call Money & $-3.43^{* *}$ & $-10.11^{* * *}$ & $-3.06^{* *}$ & $-18.20^{* *}$ & $0.78^{* * *}$ & 0.07 \\
\hline \multicolumn{7}{c}{ Deposit Yield Rate or Equivalent/Distribution/Fees/Bonuses } \\
\hline Demand Deposit Mudharabah & $-3,56$ & $-13.14^{* * *}$ & $-3.44^{* *}$ & $13.17^{* * *}$ & $0.49^{* *}$ & 0.11 \\
Saving Deposit Mudharabah & -2.58 & $-8.15^{* * *}$ & $-3.84^{* *}$ & $-15.06^{* * *}$ & $1.14^{* * *}$ & $0.51^{* *}$ \\
Time Deposit Mudharabah & & & & & \\
1-Month & -1.03 & $-9.19^{* * *}$ & -1.16 & $-14.34^{* * *}$ & $1.16^{* * *}$ & 0.12 \\
3-Month & -1.23 & $-9.18^{* * *}$ & -1.44 & $-15.12^{* * *}$ & $1.13^{* * *}$ & 0.13 \\
6-Month & -1.13 & $-9.52^{* * *}$ & -1.04 & $-16.58^{* * *}$ & $1.17^{* * *}$ & 0.09 \\
12-Month & -1.24 & $-12.36^{* * *}$ & -1.55 & $-12.83^{* * *}$ & $1.18^{* * *}$ & 0.07 \\
\hline \multicolumn{7}{c}{ Financing Rates } \\
Working Capital & -1.29 & $-13.70^{* * *}$ & -1.76 & $-13.70^{* * *}$ & $1.20^{* * *}$ & 0.10 \\
Investment & -0.66 & $-9.07^{* * *}$ & -0.60 & $-16.84^{* * *}$ & $1.10^{* * *}$ & 0.07 \\
Consumption & -077 & $-12.03^{* * *}$ & -0.99 & $-12.18^{* * *}$ & $1.10^{* * *}$ & 0.16 \\
\hline
\end{tabular}

This table presents the unit root test of the variables according to the three methods, namely Augmented DickeyFuller (ADF), Phillips-Perron (PPP) and Kwiatkowski-Phillips-Schmidt-Shin (KPSS). The null hypothesis for ADF and PP tests are that the series are non-stationary (contain unit root); conversely, the null hypothesis of the KPSS test assumes that the series are stationary (no unit root). ${ }^{* * *}=$ significant at $1 \%,{ }^{* *}=$ significant at $5 \%,{ }^{*}=$ significant at $10 \%$. 
The coefficient of the dummy variable, $\alpha_{2^{\prime}}$ shows negative signs and is significant for almost all rates both in conventional and Islamic banking. This result shows that there is substantial reduction in bank margins when the economy is in the contractionary phase. In conventional banking, the reduction in the margins of deposit rates is around $0.5 \%$ to $3.7 \%$ while the drop in those of rates is $4.5 \%$ to $5.1 \%$. Meanwhile, the reduction in margins is approximately $3.4 \%$ to $5.06 \%$ for deposit rates and around $4.14 \%$ to $7.8 \%$ for financing rates for Islamic banking. Thus, on average, the drop in the margins during the contractionary phase is larger for Islamic banks. This indicates that bank intermediation cost or margin in Islamic banking is more responsive to the business cycle.

Turning to our main theme, we may note asymmetric responses of banking rates to the policy rate by both conventional and Islamic banks. This finding does not support the previous study by Omer (2019) in Pakistan, although he does not control the business cycle of the economy. Columns (7) and (8) present the Wald statistics for testing whether the IRPT is complete for respectively the expansionary and contractionary phases. The null hypothesis in column (7) is $\mathrm{H}_{0}: \alpha_{1}=1$ and in column (8), $\mathrm{H}_{0}=\alpha_{1}+\alpha_{3}=1$. From the tests, several findings are notable.

First, for the money market rate, the IRPT tends to be different for Islamic banks and conventional banks. Complete adjustment occurs during the contractionary phase in conventional banking. Meanwhile, in Islamic banking, the complete adjustment occurs in the expansionary phase. Second, during the contractionary phase, almost all of the time deposit rates fully adjust to the monetary policy change while demand deposit and saving deposit adjust less than one-to-one to policy rate change in conventional banking. Similar behavior also exists in Islamic banking, except for long-term time deposits (12-month time deposits). Further, complete pass-through is found in lending rates in conventional banking, except for the consumption rates. While for financing rates in Islamic banking, the rates are either oversensitive or less sensitive in responding to the monetary policy change in the contractionary period. In contractionary episodes, when the economy is typically under pressure, monetary authority usually responds by introducing monetary loosening; most conventional bank rates adjust completely even though they are quite sluggish. Meanwhile, most Islamic bank rates, although adjust faster, are either stickier or over elastic. These suggest that since short-term deposit rates in both regimes are relatively lower, there is no wider space to adjust when the policy rate is accommodative. Meanwhile, with the longer-term deposit rates being relatively higher rates, banks take the opportunity to pull down the rates as an adjustment to the monetary policy loosening to reduce overall cost in adverse economic situations.

Lending rates are completely adjusted to reference rates since banks face relatively lower debt demand growth in contractionary periods, thus arguably pushing down the lending rates as the same proportion to the monetary policy rate decreases. Since financing rates in Islamic banks have persistently higher rates, when banks experience sluggish financing demand, Sharia banks should maintain their competitiveness by cutting their financing rates more than policy rate reduction. Moreover, in recessionary episodes when demand and supply of funds are distorted, banks tend to prefer more secure financial instruments like relying on central bank or government bond instruments in managing their 
liquidity, while Islamic banks have limited options for sharia-based liquidity instruments in the market. This is arguably responsible for the divergent behavior between conventional and Islamic banks rates in responses to policy rate changes. This finding also supports the study by Hamza \& Saadaoui (2018), who state that monetary policy rate change significantly influences the level of Islamic bank financing, which may be due to the excess sensitivity of financing rates in Shariabased banks.

During the expansionary period, all deposit rates do not fully adjust to policy rate change. Incomplete reverse adjustment occurs for demand and saving deposit rates in conventional banking and mudharabah time deposit rates in Islamic Banking. These findings suggest that demand and saving deposit rates are stickier in responding to monetary policy changes during expansionary and contractionary periods. When the economy performs well (expansionary phase), time deposit rates tend to be less sensitive to monetary policy; even the reverse adjustment behavior is found in Islamic banking for time deposit rates. In expansionary periods that are typically characterized by tighter monetary policy, most deposit rates in conventional banks adjust incompletely, which indicates non-competitiveness in the deposit markets (Rosen, 2002; Zulkhibri, 2012).

Further, except for the lending rate for consumption, complete pass-through is found in conventional banks' lending rates. While for financing rates in Islamic banking, the rates are either oversensitive or less sensitive to changes in monetary policy during the contractionary period. Interestingly, in the expansionary period, lending rates and financing rates for working capital, investment, and consumption are inversely related to policy rate changes. This finding is consistent with the previous studies that the degree of policy rate pass-through to consumer lending rates seems to be the lowest as compared to other types of lending rates (Gregor et al., 2009; Handayani \& Kacaribu, 2021).

The shift in the pass-through is also observed across the business cycle phases. The positive and significant estimated coefficient of the interaction between policy rate and recession dummy, i.e. $\alpha_{3}$, for all deposit rates and lending rates or financing rates suggest the increased pass-through during the contractionary period. In other words, the pass-through to these rates is lower during the expansionary phase. In the same token, banking rates become unresponsive or rigid as monetary policy changes during the period of expansion. This finding also confirms the correlation analysis results, that banking rates have a higher correlation or are more linked to monetary policy rate in the contractionary period.

Further, the magnitude of long-run pass-through is found to be asymmetric, as demonstrated by the significant of the Wald statistics for all banking rates, presented in column (9) with the null hypothesis, $H_{0}: \alpha_{1}=\alpha_{1}+\alpha_{3}$. This means that the degree to which the banking rates respond to the policy rate change is different between the expansionary and contractionary phases for both conventional and Islamic banking.

\subsection{Short-Run Dynamics}

The short-run dynamics of banking rates is presented in Table 5. In conventional banking, our findings are consistent with Handayani \& Kacaribu (2021); the 
significant estimated coefficients of contemporaneous change in policy rate are found only in money market rates, short-term time deposit rate, and lending rate for investment. A similar rate behavior is also found in Islamic banking. This means that the monetary policy change has no direct and immediate influence on most deposit and lending or financing rates in conventional and Islamic banking during the expansionary period. We also fine the coefficients for the interaction between the recession and policy rate to be insignificant in almost all conventional and Islamic banking rates. This suggests that the business cycle does not affect the immediate or short run impact of policy rate on bank rates for both types of banks.

We further analyze the adjustment speed of banking rates, as reflected by the estimated coefficients of the error correction term presented in column (3). The significant and negative signs are present in almost all banking rates in both banking regimes. This indicates the existence of mean-reverting behavior in banking rates in both conventional and Islamic banking regimes in Indonesia. In the money market, the adjustment in the interbank call money rate of conventional banking is faster than sharia interbank call money of Islamic banking, with the adjustment speed of $83 \%$ and $41 \%$, respectively.

Furthermore, the speed of adjustment for deposit rates is higher in the Islamic banking regime than in the conventional one. The speed rate ranges from $21.4 \%$ to $75.38 \%$ in Islamic banking and $9.15 \%$ to $42.92 \%$ in conventional banking. The pattern is also similar for lending and financing rates; the financing rates of Islamic banking adjust faster than the lending rate of conventional banking regime, with the rate of speed ranging from $20.68 \%$ for financing rate for working capital to $36.82 \%$ for financing rates for consumptions and ranging from $2.39 \%$ for lending rate for working capital to $6.63 \%$ for lending rate for consumption. In addition, in conventional banks, the adjustment lag (absolute value of MAL) of the interest rates increases in the contractionary period except for Interbank Call Money and Saving Deposit. As for the Islamic banking rates, the adjustment lag of money market rate and mudharabah saving deposit decrease in the recessionary period. In general, conventional bank rates adjust more sluggishly as compared to the Islamic bank rates. We suspect that Islamic bank rates have a wider gap to the market equilibrium rates than those in conventional banks; thus, when there is a reference rate swift, they amend the gap immediately, as suggested by Handayani \& Kacaribu (2021).

Lastly, we find that the contractionary and expansionary phases do not significantly affect the speed adjustment. We find that the estimated coefficients of the interaction term shown in column (4) are not significant for all rates for both conventional and Islamic banking regimes in Indonesia.

\section{CONCLUSION AND RECOMMENDATION}

\subsection{Conclusion}

This paper empirically examines the responses of banking rates of both conventional and sharia banking regimes to changes in monetary policy during contractionary and expansionary episodes for the case of Indonesia. We find evidence that the long-run monetary policy rate pass-through depends on the phases of the business cycle. On average, the degree of policy rates pass-through to deposit rates 
in the contractionary period is improved in conventional and Islamic banking. Meanwhile, full pass-through occurs for lending rates of conventional banking in the contractionary phase. By contrast, financing rates of Islamic banking are observed to be over-responsive for working capital and investment financing rates and less responsive for consumption financing rate during the contractionary phase and move inversely to the policy rate during the expansionary phase.

Further, the short-run adjustment analysis finds that the policy rate has no direct and immediate impact on most banking rates, both in conventional and Islamic banking. Banking rates in sharia banking adjust faster to a policy rate change compared to those in conventional banking. Lastly, we conclude that business cycle episodes in Indonesia do not affect the immediate or short-run pass-through to most banking rates.

The change and unsynchronized behavior of banking rates, mainly those of sharia-based banks during the recessionary period brings out the challenge to the monetary policy management to stabilize the economy. Furthermore, this phenomenon reiterates the inability of Islamic banking to support counter-cyclical policy measures to smooth the economy or accelerate economic recovery from recession in Indonesia.

\subsection{Recommendation}

The empirical findings suggest the divergent response of banking rates in conventional and Islamic banking to monetary policy rate change. We argue that this is due to imperfect market competition and the depth of money market instruments. Since most Islamic banks' rates adjust incompletely and behave asynchronously to the policy rates, promoting policy that could improve market competition in the Islamic banks by encouraging expansion or inviting more players to enter this business is needed to improve scale efficiency. Further, consumers' preference towards Islamic bank products and services is generally due to religious sentiment (Feroz \& Siddiqui, 2018; Sari, Wibowo \& Suprapto, 2015; Januri et al., 2021). This condition arguably could offer the Islamic banking management space to incite moral hazard and create a business environment that hinders Islamic banks from pursuing efficiency and productivity orientation. Strengthening the capacity building for employees and management as well as enhancing supervision, assistance, and assessment for the Islamic bank industry is needed.

Moreover, promoting various sharia-based financial instruments for Islamic banking could improve the ability of Islamic banking to manage their liquidity to reduce risk, and the central bank could enhance the liquidity framework for Islamic banks to promote effective liquidity management for Islamic banks in Indonesia. Lastly, financial sector stakeholders (regulators, supervisors, business players) should work together to enhance financial literacy and education to promote more rational consumers, which could reduce asymmetric information and create better competition in the financial sector.

Note that we used a linear model in observing the degree of monetary policy rate pass-through to banking rates. Improvement can be made in future research by employing the model that captured the asymmetric adjustment of banking rates 
to a tightening or loosening monetary policy. A nonlinear model can be applied to further examine the presence of a nonlinear relationship between the policy rate and banking rates. Furthermore, a more rigorous study is needed to uncover the factors that account for those mentioned Islamic banking rates behavior towards monetary policy rate.

\section{REFERENCES}

Abedifar, P., Ebrahim, S. M., Molyneux, P., \& Tarazi, A. (2015). Islamic banking and finance: Recent empirical literature and directions for future research. Journal of Economic Surveys, 29(4), 637-670.

Akhatova, M., Zainal, M. P., \& Ibrahim, M. H. (2016). Banking models and monetary transmission mechanisms in Malaysia: Are Islamic banks different? Economic Papers, 35(2), 169-183.

Apergis, N., \& Cooray, A. (2015). Asymmetric interest rate pass-through in the U.S., the U.K., and Australia: New evidence from selected individual banks. Journal of Macroeconomics, 45(September 2015), 155-172.

Aragon, E. K. S. B., \& Portugal, M. S. (2009). Asymmetric effects of monetary policy in Brazil. Estudos Econômicos, 39(2), 277-300.

Aristei, D., \& Gallo, M. (2014). Interest rate pass-through in the Euro area during the financial crisis: A multivariate regime-switching approach. Journal of Policy Modeling, 36(2), 273-295.

Ascarya, A. (2007). Optimum monetary policy under dual financial / banking system. Proceedings of the $2^{\text {nd }}$ Islamic Conference 2007 (iECONS2007). Faculty of Economics and Muamalat, Islamic Science University of Malaysia.

Ascarya, A. (2012). Transmission channel and effectiveness of dual monetary policy in Indonesia. Buletin Ekonomi Moneter dan Perbankan (Bulletin of Monetary Economics and Banking), 14(3), 269-298.

Atkin, T., \& La Cava, G. (2017). The transmission of monetary policy: How does it work? Reserve Bank of Australia Bulletin, September, pp. 01-08.

Audah, M. T., \& Kasri, R. A. (2020). Does Islamic banking matter in transmitting monetary policy? empirical evidence from Indonesia and Malaysia. Pertanika Journal of Social Sciences and Humanities, 28(1), 679-694.

Avouyi-Dovi, S., Horny, G., \& Sevestre, P. (2017). The stability of short-term interest rates pass-through in the euro area during the financial market and sovereign debt crises. Journal of Banking and Finance, 79(June 2017), 74-94.

Aysan, A. F., Disli, M., \& Ozturk, H. (2018). Bank lending channel in a dual banking system: Why are Islamic banks so responsive? World Economy, 41(3), 674-698.

Bernanke, B. (1983). Nonmonetary effects of the financial crisis in the propagation of the great depression. The American Economic Review, 73(3), 257-276.

Bilgin, M. H., Danisman, G. O., Demir, E., \& Tarazi, A. (2021). Economic uncertainty and bank stability: Conventional vs. Islamic banking. Journal of Financial Stability, 56(October 2021), 1-20.

Boivin, J., Kiley, M. T., \& Mishkin, F. S. (2010). How has the monetary transmission mechanism evolved over time? In Benjamin M. Friedman \& Michael Woodford (Eds.), Handbook of Monetary Economics (Vol.3), 369-422, Elsevier. 
Caporale, G. M., Çatık, A. N., Helmi, M. H., Menla Ali, F., \& Tajik, M. (2020). The bank lending channel in the Malaysian Islamic and conventional banking system. Global Finance Journal, 45(August 2020), 1-26.

Cevik, S. \& Charap, J. (2011). The behavior of conventional and Islamic bank deposit returns in Malaysia and Turkey. IMF Working Paper. No. WP/11/156.

Cevik, S., \& Teksoz, K. (2013). Lost in transmission? The effectiveness of monetary policy transmission channels in the GCC countries. Middle East Development Journal, 5(3), 1-21.

Chong, B. S. (2010). Interest rate deregulation: Monetary policy efficacy and rate rigidity. Journal of Banking and Finance, 34(6), 1299-1307.

Dixit, A. K., \& Pindyck, R. S. (1994). Investment under uncertainty. Economics Books 1(5474). New Jersey, USA: Princeton University Press

Dolado, J. J., \& Maria-Dolores, R. (2006). State asymmetries in the effects of monetary policy shocks on output: Some new evidence for the Euro-Area. In Milas, C., Rothman, P.A., van Dijk, D., \& Wildasin, D.E., (Eds.) Nonlinear Time Series Analysis of Business Cycles (Contributions to Economic Analysis, 276), 311331. Bingley: Emerald Group Publishing Limited.

Feroz, B., \& Siddiqui, D. A. (2018). Factors influencing customers to opt for Islamic banking. International Journal of Management and Commerce Innovations, 6(2), 261-269.

Fikri, R. J. (2018). Monetary transmission mechanism under dual financial system in Indonesia: Credit-financing channel. Journal of Islamic Monetary Economics and Finance, 4(2), 251-278.

Garcia, R., \& Schaller, H. (2002). Are the effects of monetary policy asymmetric? Economic Inquiry, 40(1), 102-119.

Gregor, J., Melecky, A., \& Melecky, M. (2019). Interest rate pass-through: A metaanalysis of the literature. World Bank Policy Research Working Paper No. 8713, Washington DC.

Hafidh, A. A. (2021). Responses of Islamic banking variables to monetary policy shocks in Indonesia. Islamic Economic Studies, 28(2), 174-190.

Hamza, H., \& Saadaoui, Z. (2018). Monetary Transmission through the debt financing channel of Islamic banks: Does PSIA play a role? Research in International Business and Finance, 45(October 2018), 557-570.

Handayani, F. A., \& Kacaribu, F. (2021). Asymmetric transmission of monetary policy to interest rates: Empirical evidence from Indonesia. Buletin Ekonomi Moneter dan Perbankan (Bulletin of Monetary Economics and Banking), 24(1), 119150.

Hodrick, R. J., \& Prescott, E. C. (1997). Postwar US business cycles: An empirical investigation. Journal of Money, Credit, and Banking, 29(1), 1-16.

Hofmann, B., \& Mizen, P. (2004). Interest rate pass-through and monetary transmission: Evidence from individual financial institutions' retail rates. Economica, 71(281), 99-123.

Holton, S., \& Rodriguez d'Acri, C. (2018). Interest rate pass-through since the Euro area crisis. Journal of Banking and Finance, 96(November 2018), 277-291.

Hristov, N., Hülsewig, O., \& Wollmershäuser, T. (2014). The interest rate passthrough in the Euro area during the global financial crisis. Journal of Banking and Finance, 48(November 2014), 104-119. 
Humala, A. (2005). Interest rate pass-through and financial crises: Do switching regimes matter? The case of Argentina. Applied Financial Economics, 15(2), 7794.

Hussain, M. N., \& Nahar, B. (2016). Interest rate volatility and retail interest rate pass-through in the case of the Malaysian economy. The Journal of Developing Areas, 50(5), 277-294.

Ibrahim, M. H., \& Law, S. H. (2019). Financial intermediation costs in a dual banking system: The role of Islamic banking. Buletin Ekonomi Moneter dan Perbankan (Bulletin of Monetary Economics and Banking), 22(4), 529-550.

Jannsen, N., Potjagailo, G., \& Wolters, M. H. (2019). Monetary policy during financial crises: Is the transmission mechanism impaired? International Journal of Central Banking, 15(4), 81-126.

Januri, S. S., Pozi, M. A. M., Nadzri, M. H., \& Zainuddin, M. S. (2021). Factors influencing of Islamic banking by customers: A case study in Northern Malaysia. International Journal of Academic Research in Business and Social Sciences, 11(7), 720-735.

Karagiannis, S., Panagopoulos, Y., \& Vlamis, P. (2010). Interest rate pass-through in Europe and the US: Monetary policy after the financial crisis. Journal of Policy Modeling, 32(3), 323-338.

Kassim, S. H., Majid, M. S. A., \& Yusof, R. M. (2009). Impact of monetary policy shocks on the conventional and Islamic banks in a dual banking system: Evidence from Malaysia. Journal of Economic Cooperation and Development, 30(1), 41-58.

Kaufmann, S. (2002). Is there an asymmetric effect of monetary policy over time? a bayesian analysis using austrian data. Empirical Economics, 27(2), 277-297.

Li, X. L., Si, D. K., \& Ge, X. (2021). China's interest rate pass-through after the interest rate liberalization: Evidence from a nonlinear autoregressive distributed lag model. International Review of Economics and Finance, 73(December 2020), 257274.

Liu, M. H., Margaritis, D., \& Qiao, Z. (2016). The global financial crisis and retail interest rate pass-through in Australia. Review of Pacific Basin Financial Markets and Policies, 19(4), 1 - 32.

Omer, M. (2019). Monetary policy pass-through, excess liquidity and price spillover: A comparative study of conventional and Islamic banks of Pakistan. Journal of Islamic Monetary Economics and Finance, 5(2), 287-320.

Peersman, G., \& Smets, F. (2001). Are the effects of monetary policy in the euro area greater in recessions than in booms? European Central Bank Working Paper Series 52, March 2001.

Rosen, R. J. (2002). What goes up must come down? Asymmetries and persistence in bank deposit rates. Journal of Financial Services Research, 21(3), 173-193.

Rousseas, S. (1985). A markup theory of bank loan rates. Journal of Post Keynesian Economics, 8(1), 135-144.

Ryandono, M. N. H. (2006). Mempertanyakan Kebenaran Paradigma Hubungan Bunga, Investasi (Kredit), dan Pertumbuhan Ekonomi: Haramnya Sistem Bunga (Riba) Secara Teoritik dan Empirik [Questioning the Truth of the Paradigm of Interest, Investment (Credit) and Economic Growth: The Haram System of Interest (Riba) Theoretically and Empirically]. Paper Presented in National Seminar and Colloquium, ITB. Bandung, Indonesia: SBM-ITB, September. 
Sander, H., \& Kleimeier, S. (2004). Convergence in European retail banking? What interest rate pass-through tells us about monetary policy transmission, competition and integration. Journal of International Money and Finance, 23(3), 461-492.

Sari, I. M., Wibowo, H., \& Suprapto, E. (2015). Factors that influenced people to become Islamic bank customer: A study on Kancana Villagers. AlIqtiswarjiyohad: Journal of Islamic Economics, 7(1), 73-86.

Stiglitz, J., \& Weiss, A. (1981). Credit rationing in markets with imperfect information. American Economic Review, 71(3), 393-410.

Sukmana, R. (2015). Economic Sectors sensitivity to Islamic and conventional monetary instruments: Case study in Indonesia. In El-Karanshawy, H. A., A. Omar, T. Khan, S. S. Ali, H. Izhar, W. Tariq, K. Ginena, and B. Al Quradaghi (Eds.), Islamic Economics: Theory, Policy and Social Justice, Vol. 2, Doha: Bloomsbury Qatar Foundation Journal.

Takáts, E. (2012). Countercyclical Policies in Emerging Markets. BIS Quarterly Review, June 4, 2012. Available at SSRN: https://ssrn.com/abstract=2100442

Trinugroho, I., Risfandy, T., \& Ariefianto, M. D. (2018). Competition, diversification, and bank margins: Evidence from Indonesian Islamic rural banks. Borsa Istanbul Review, 18(4), 349-358.

Valadkhani, A., \& Anwar, S. (2012). Interest rate pass-through and the asymmetric relationship between the cash rate and the mortgage rate. The Economic Record, 88(282), 341-350.

Yüksel, E., \& Özcan, K. M. (2013). Interest rate pass-through in Turkey and impact of global financial crisis: Asymmetric threshold cointegration analysis. Journal of Business Economics and Management, 14(1), 98-113.

Zaheer S., Ongena, S., \& van Wijnbergen, S.J.G. (2013). The transmission of monetary policy through conventional and Islamic banks. International Journal of Central Banking, 9(4), 175-224.

Zulkhibri, M. (2012). Policy rate pass-through and the adjustment of retail interest rates: Empirical evidence from Malaysian financial institutions. Journal of Asian Economics, 23(4), 409-422.

Zulkhibri, M., \& Sukmana, R. (2017). Financing channels and monetary policy in a dual banking system: Evidence from Islamic banks in Indonesia. Economic Notes, 46(1), 117-143.

Zulkhibri, M. (2018). The Impact of monetary policy on Islamic bank financing: Bank-level evidence from Malaysia. Journal of Economics, Finance and Administrative Science, 23(46), 306-322. 


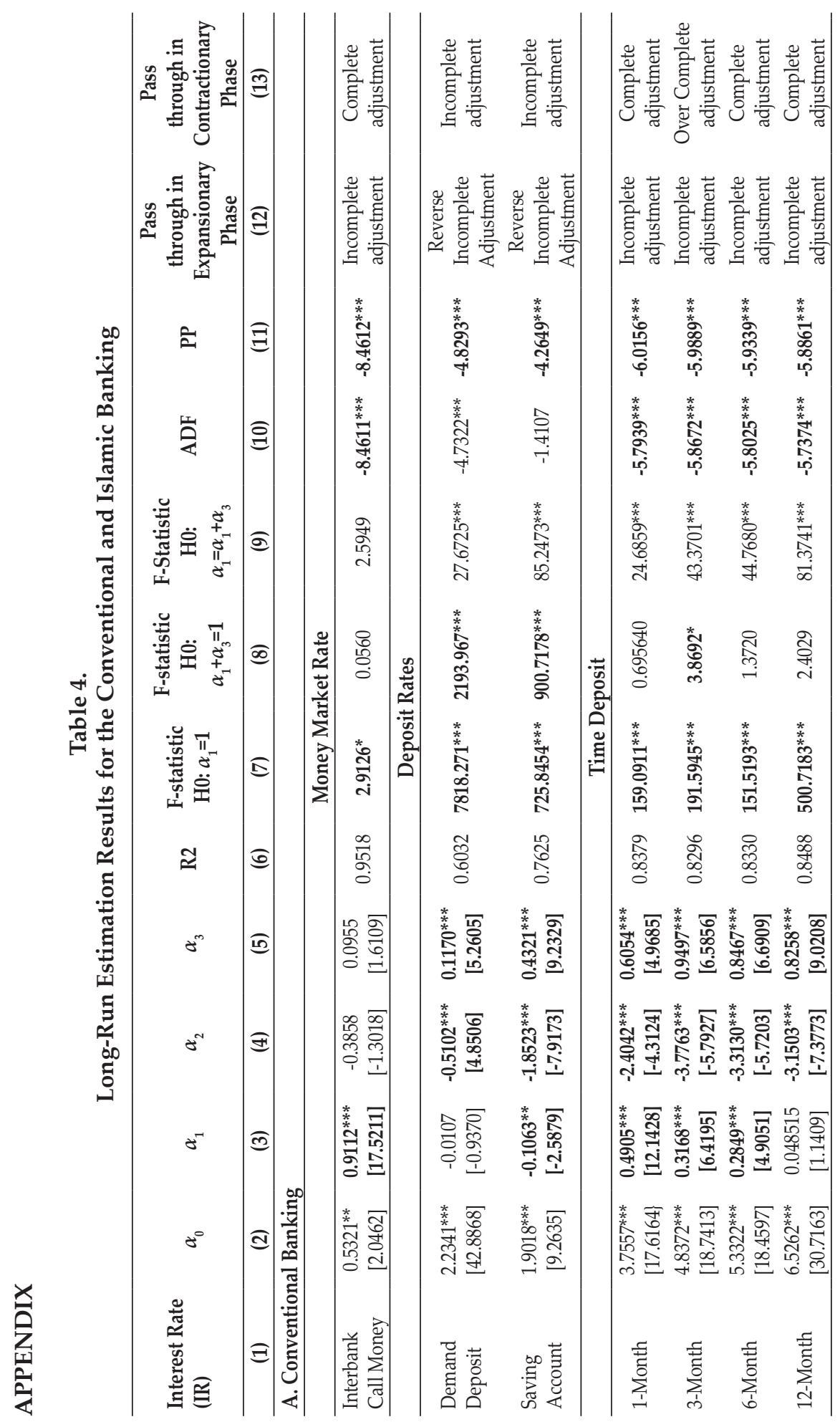




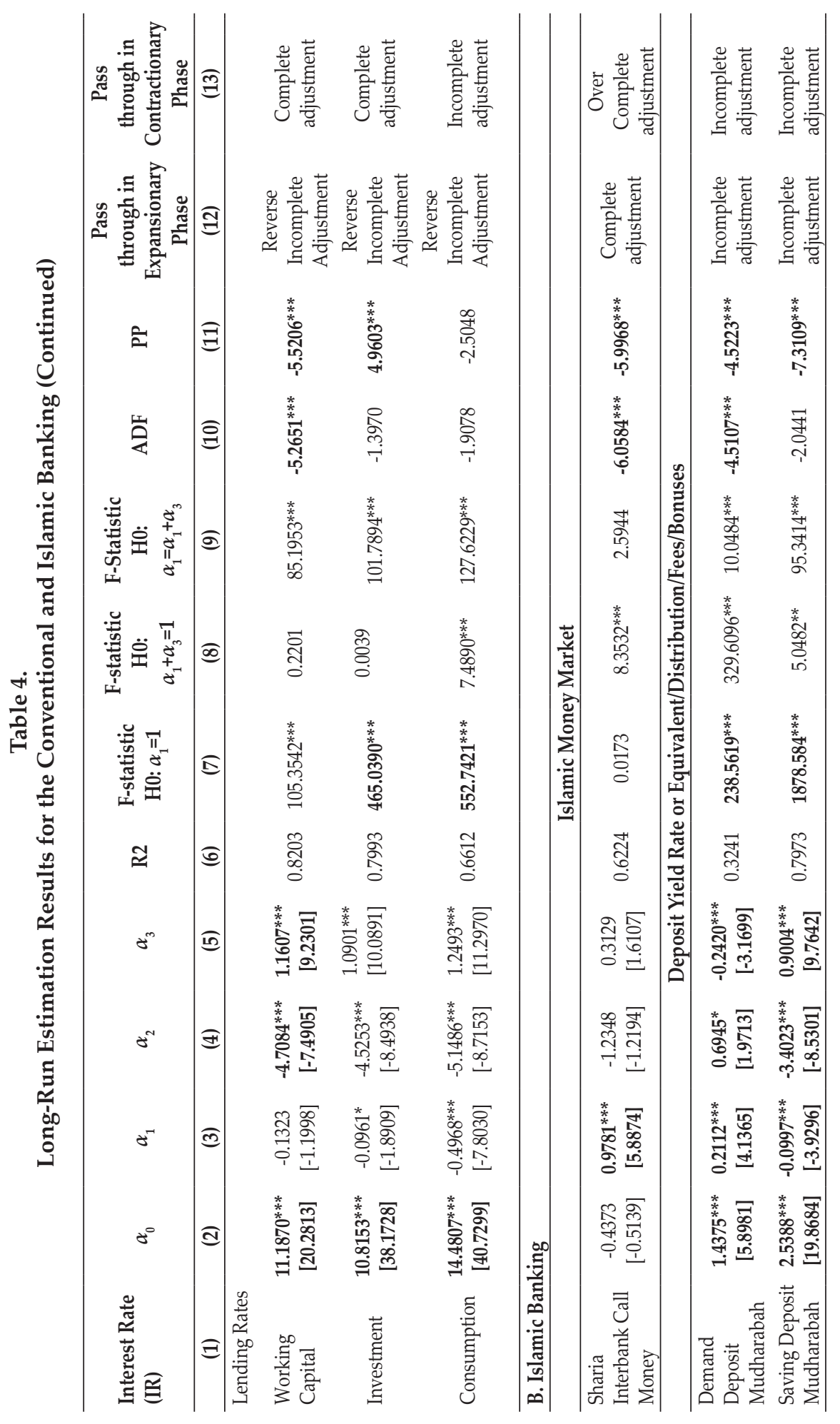




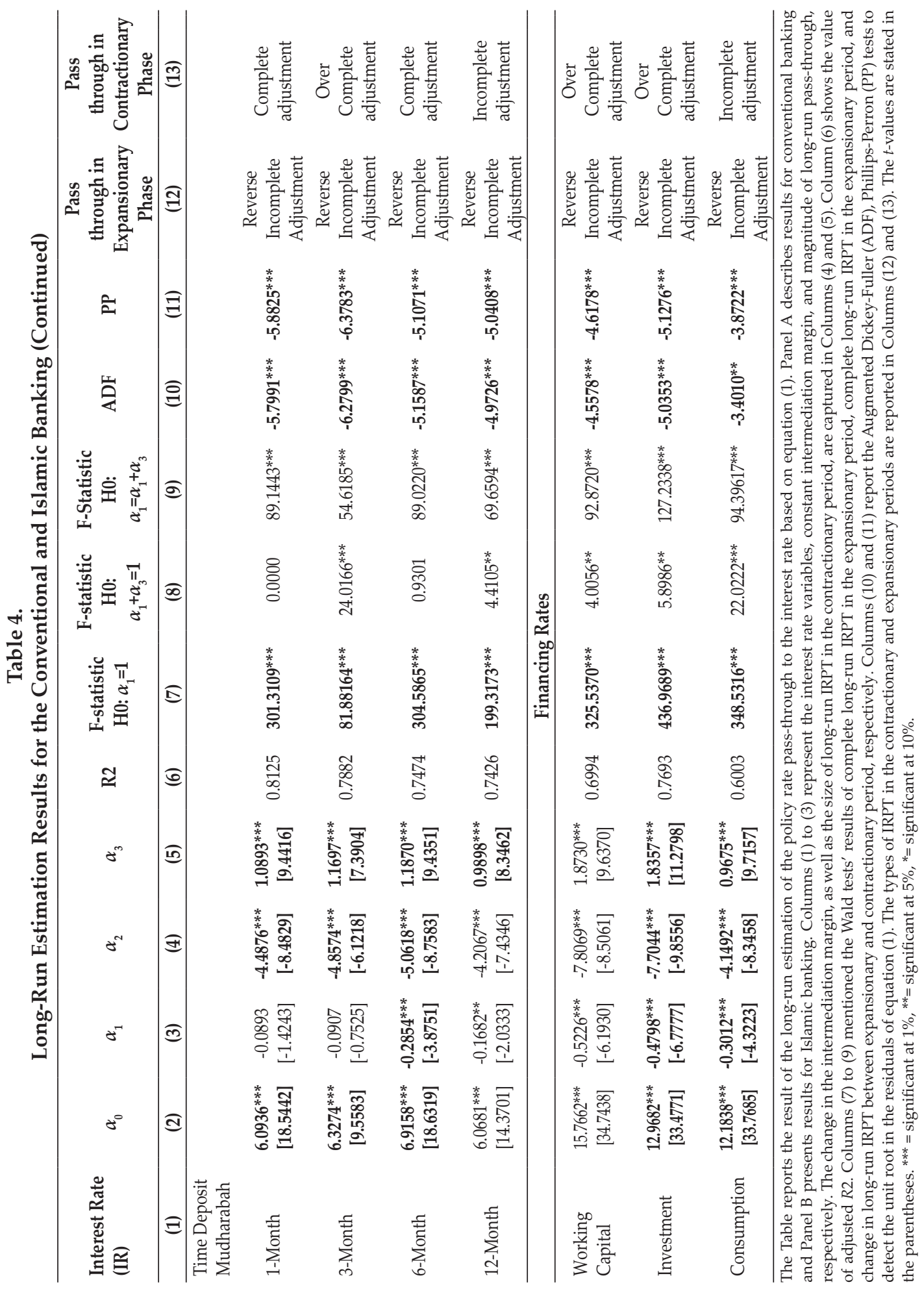




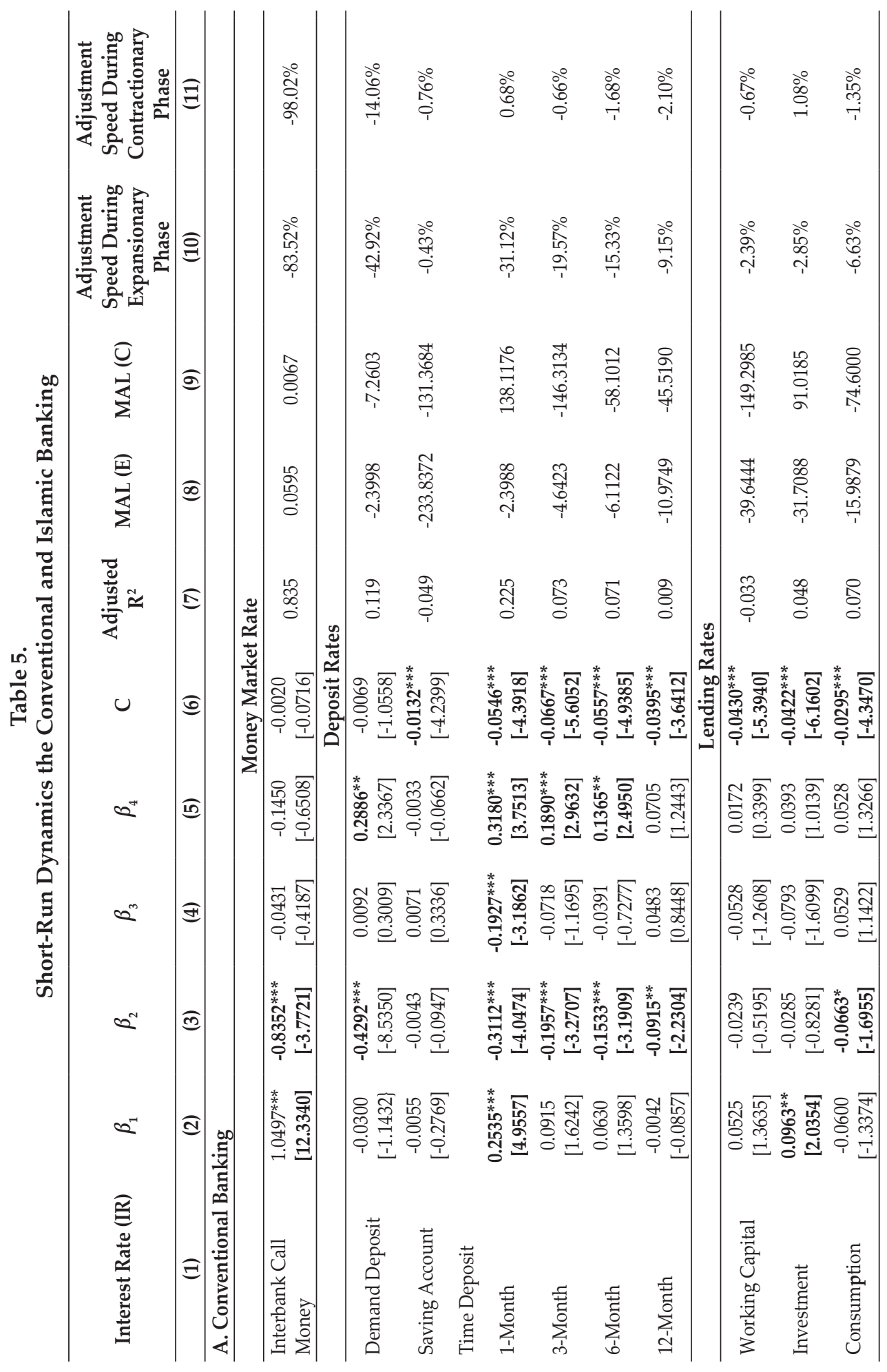




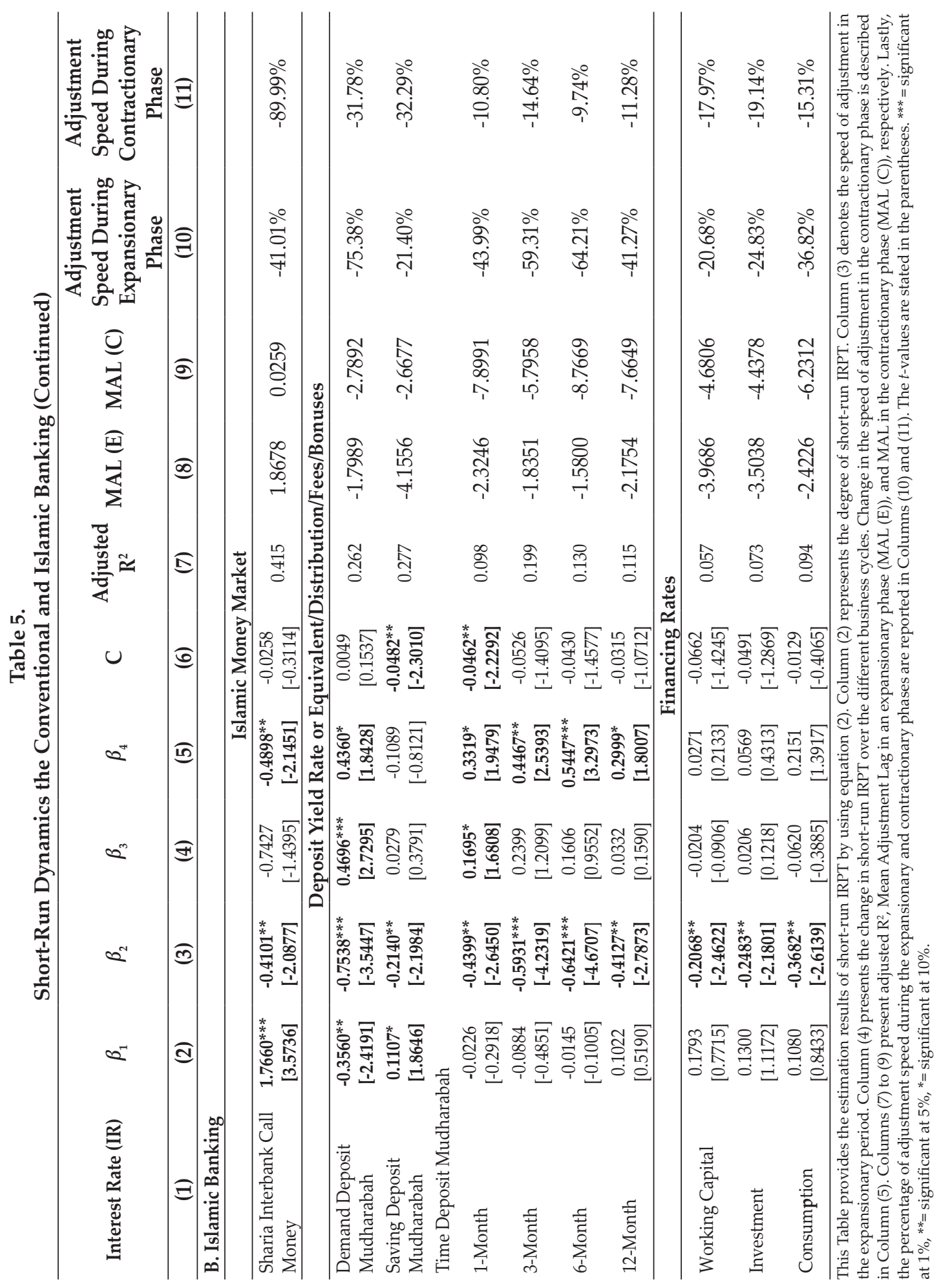


This page is intentionally left blank 